\title{
Gambaran Kesejahteraan Psikologis pada Karyawan Terdampak Pandemi COVID-19
}

\author{
Psychological Well-Being of Employees during the COVID-19 Pandemic \\ Umi Anugerah Izzati, Meita Santi Budiani, Olievia Prabandini Mulyana, \\ Ni Wayan Sukmawati Puspitadewi \\ Program Studi Psikologi Universitas Negeri Surabaya, Indonesia
}

\begin{abstract}
This research discusses the psychological well-being of employees affected by COVID-19 pandemic. This research was a descriptive study that used a quantitative approach. The subjects in the study were 118 employees who are working in an educational institution. Data were collected using the psychological well-being scale which was constructed based on the Ryff's (1989) concept of psychological well-being. Data analysis were carried out by compiling categorization and cross-tabulating in order to determine the psychological well-being of employees. The results showed that the psychological well-being of employees was in the high category. The dimension of psychological well-being that stands out is the life purpose, followed by the positive relationships with others.
\end{abstract}

Keywords: Psychological well-being, employees, COVID-19 pandemic

\begin{abstract}
Abstrak: Penelitian ini membahas mengenai gambaran kesejahteraan psikologis pada karyawan terdampak pandemi COVID-19. Penelitian ini merupakan penelitian deskriptif yang menggunakan pendekatan kuantitatif. Subjek dalam penelitian adalah 118 karyawan yang bekerja di salah satu institusi pendidikan. Data dikumpulkan menggunakan skala kesejahteraan psikologis yang disusun berdasarkan konsep kesejahteraan psikologis dari Ryff (1989). Analisis data dilakukan dengan menyusun kategorisasi dan melakukan tabulasi silang guna mengetahui kesejahteraan psikologis karyawan. Hasil penelitian menunjukkan kesejahteraan psikologis yang dimiliki karyawan masuk ke dalam kategori tinggi. Dimensi kesejahteraan psikologis yang menonjol adalah tujuan hidup, dilanjutkan dengan hubungan positif dengan orang lain.
\end{abstract}

Kata kunci: Kesejahteraan psikologis, karyawan, pandemi COVID-19

Penyebaran pandemi COVID-19 telah memberikan pengaruh pada semua sektor kehidupan di masyarakat. Beberapa upaya dalam menghentikan wabah COVID-19 ini telah dilakukan di antaranya dengan memberlakukan bekerja dari rumah, memberikan jam kerja yang lebih fleksibel, ataupun menutup banyak institusi yang meliputi sekolah, universitas, dan institusi pendi- dikan lainnya (Bozkurt \& Sharma, 2020). Terjadinya penutupan instansi pendidikan selama pandemi telah memengaruhi kondisi banyak siswa dan dampaknya masih belum dapat dipastikan (Flores \& Gago, 2020). Situasi pandemi saat ini telah memaksa hampir semua lembaga pendidikan pada tiap tingkatan untuk beroperasi secara jarak jauh dan menerapkan sistem pembela-

Korespondensi tentang artikel ini dapat dialamatkan kepada Umi Anugerah Izzati melalui email: umianugerah@unesa.ac.id 
belajaran jarak jauh (Bozkurt \& Sharma, 2020).

Kegiatan bekerja dari rumah atau disebut "work from home" yang diterapkan pada seluruh instansi pendidikan ini memiliki beberapa keuntungan dan kerugian bagi tenaga kependidikan dalam menjalankan pekerjaannya. Salah satu keuntungan ketika melakukan pekerjaan dari rumah, tentunya menjadi sangat fleksibel, dimana karyawan dapat menyelesaikan pekerjaannya dengan caranya sendiri. Penelitian Purwanto (2020) melaporkan bahwa ketika bekerja dari rumah seorang tenaga pendidik dan kependidikan dapat menyesuaikan tingkat kenyamanannya selama bekerja. Selain itu, dengan adanya fleksibilitas waktu dalam bekerja, karyawan dapat meminimalisir stres yang diakibatkan bebas tugasnya sehingga akan meningkatkan produktivitas dan efektivitas dalam bekerja. Selain itu, selama ada keuntungan pasti juga ada kerugian yang akan dirasakan. Kerugian diberlakukannya work from home (WFH) ini bagi kinerja seorang tenaga pendidik ataupun kependidikan yaitu menurunnya motivasi kerja, yang dapat disebabkan karena beberapa hal seperti, lingkungan yang tidak kondusif, terganggu oleh adanya media sosial maupun hiburan-hiburan lainnya, serta terkendala pada listrik dan internet (Purwanto, 2020).

Pada kondisi saat pandemi COVID-19, adakalanya muncul stres. Stresor terdiri dari primer dan sekunder. Menurut López et al (2020) stresor primer seperti masalah langsung ataupun tidak langsung yang diakibatkan oleh COVID-19 dapat menciptakan tekanan emosional pada individu. Menurut Setyawati dan Murniati (2018), stresor sekunder terjadi ketika individu menentukan kapasitas mereka untuk mengelola tuntutan lingkungan. Selaras dengan hal tersebut dapat dikatakan bahwa karyawan-karyawan yang mengalami berbagai permasalahan dalam pekerjaannya akibat pandemi, bukan hanya mengganggu perekonomian melainkan juga psikologis mereka.Syahrial (2020) mengemukakan bahwa para karyawan tidak hanya mengalami kesulitan dalam aspek ekonomi, akan tetapi juga kesehatan. Selain itu, kondisi saat ini juga menimbulkan kekhawatiran bagi para guru karena mereka belum mendapat banyak pelatihan untuk melakukan pengajaran online. Ditambah lagi, adanya penutupan sekolah, karantina rumah, dan jarak sosial yang diterapkan dapat menyebabkan kecemasan mendadak di antara pendidik (Talidong \& Toquero, 2020). Selain itu, tidak semua pelajar, siswa dan mahasiswa terbiasa belajar melalui online. Apalagi guru dan dosen masih ada yang belum mahir mengajar dengan menggunakan teknologi internet atau media sosial (Rokhani, 2020). Individu yang dapat mengelola dengan baik penyebab terjadinya stres maka akan dapat mempertahankan kesejahteraan psikologisnya yang akhirnya akan membuat mereka mampu menilai suatu peristiwa dengan perspektif yang lebih positif (López et al., 2020).

Kesejahteraan psikologis merupakan kemampuan individu dalam menjalani kehidupan sosial dan membangun hubungan hangat dengan orang lain, memiliki tujuan dalam menjalani hidup, mampu menerima diri, kemauan untuk terus menyalurkan potensi diri, mandiri jika dihadapkan dengan tekanan sosial, serta mampu mengontrol lingkungan eksternalnya (Ryff \& Keyes, 1995). Untuk mencapai kesejahteraan psikologis yang baik, salah satunya diperlukan kondisi mental yang sehat. Faktor-faktor yang dapat memengaruhi tingkat kesejahteraan psikologis tiap individu adalah faktor demografis yang meliputi usia, status pernikahan, status sosial ekonomi dan budaya, pendidikan, jenis kelamin, dan faktor dukungan sosial, religiusitas, kepribadian, serta faktor evaluasi terhadap pengalaman (Ryff, 1989).

Faktor yang dapat memengaruhi tingkat kesejahteraan psikologis terbagi atas dua. Pertama, tingkat organisasi yang meliputi dukungan sosial; dan kedua adalah tingkat individu yang meliputi ciri afektif, kepribadian, dan karakteristik demografis individu (Cho, 2019). Huppert (2009) juga menyebutkan faktor yang memengaruhi kesejahteraan psikologis adalah dukungan 
sosial, kepribadian, usia, jenis kelamin dan status sosial ekonomi.

Beberapa penelitian tentang kesejahteraan psikologis telah dilakukan oleh para peneliti terdahulu di antaranya penelitian Awaliyah dan Listiyandini, (2018) terhadap subjek mahasiswa. Hasil penelitian ini menunjukkan bahwa rasa kesadaran berperan secara positif dan signifikan terhadap dua dimensi kesejahteraan psikologis, yaitu dimensi penerimaan diri dan penguasaan lingkungan. Penelitian lain oleh Aisyah dan Chisol (2018) mengkaji rasa syukur kaitannya dengan kesejahteraan psikologis pada guru honorer Sekolah Dasar. Hasil penelitian ini menunjukkan bahwa terdapat hubungan yang positif dan siginifikan antara rasa syukur dengan kesejahteraan psikologis. Penelitian lain dilakukan oleh Idris et al. (2019) terhadap subjek sarjana dari tiga universitas negeri di Malaysia. Hasil penelitian ini menunjukkan bahwa terdapat hubungan yang signifikan antara resiliensi dengan kesejahteraan psikologis.

Adapun letak perbedaan antara penelitian terdahulu dengan penelitian saat ini adalah pada penelitian terdahulu lebih memfokuskan pada variabel-variabel yang mempengaruhi kesejahteraan psikologis pada subjek penelitian pada situasi umum. Sementara itu, penelitian ini berfokus pada gambaran kesejahteraan psikologis pada karyawan yang bekerja di salah satu institusi pendidikan selama masa pandemi COVID19. Berdasarkan uraian yang telah dikemukakan di atas maka peneliti tertarik untuk mengetahui gambaran kesejahteraan psikologis pada karyawan terdampak pandemi COVID-19.

\section{Metode}

\section{Sampel}

Subjek dalam penelitian ini adalah karyawan yang bekerja pada salah satu institusi pendidikan yang saat ini terdampak pandemi COVID-19, dengan rentang usia dari <30 sampai dengan >50 tahun dan sebagian besar subjek berada di rentang usia
30-40 tahun. Sampel diperoleh menggunakan teknik convenience sampling, dimana pengambilan sampel mengandalkan spontanitas. Semua orang yang memiliki kesesuaian karakteristik subjek yang ingin diukur dapat menjadi subjek ketika mengisi instrumen skala kesejahteraan psikologis yang disebarkan secara online menggunakan google form. Jumlah subjek penelitian ini adalah 118 karyawan sebuah institusi pendidikan, yang terdiri dari 60 karyawan berjenis kelamin pria dan 58 wanita.

\section{Pengumpulan Data}

Penelitian ini menggunakan instrumen berupa skala untuk mengukur kesejahteraan psikologis karyawan. Skala ini disusun oleh tim peneliti dengan berlandaskan teori dan dimensi dari Ryff (1989) yaitu penerimaan diri, hubungan positif dengan orang lain, otonomi, penguasaan lingkungan, tujuan hidup, dan perkembangan pribadi.

Sebelum melakukan pengambilan data, dilakukan uji coba instrumen skala kesejahteraan psikologis untuk melihat reliabilitas dan validitas dari skala yang digunakan. Berdasarkan hasil pengujian reliabilitas melalui teknik statistik Cronbach's Alpha, ditemukan koefisien reliabilitas sebesar 0.935 yang menandakan skalanya tergolong sangat reliabel. Koefisien reliabilitas dianggap memuaskan apabila berada pada angka 0,90 atau lebih tinggi (Azwar, 2019). Selanjutnya uji validitas alat ukur dilakukan dengan menggunakan product moment Pearson, dan menghasilkan 30 aitem valid dari total 36 aitem dengan daya beda aitem mulai dari $0.385-0.715$.

\section{Analisis Data}

Penelitian ini menggunakan teknik analisis statistik deskriptif menggunakan bantuan SPSS 22.0 for Windows untuk menemukan gambaran data responden. Analisis data melibatkan pengkategorian pada nilai skor yang telah dimiliki, untuk mengetahui tingkat persepsi kesejahteraan psikologis dari para responden. Selanjutnya, 
dilakukan tabulasi silang (cross tabulation), untuk mengetahui hubungan antara jenis kelamin dengan kesejahteraan psikologis, serta kaitannya dengan dimensi-dimensi dari kesejahteraan psikologis.

\section{Hasil}

Penelitian ini merupakan penelitian deskriptif kuantitatif yang bertujuan untuk menggambarkan keadaan suatu populasi tertentu dengan melakukan analisis data yang kemudian diolah menggunakan perhitungan statistik.

Berikut ini disajikan ringkasan profil dari subjek penelitian yang meliputi jenis kelamin, usia dan status pernikahan pada Tabel 1. Data menunjukkan bahwa sebagian besar subjek berjenis kelamin pria dengan frekuensi sebanyak 60 subjek (51\%). Berdasarkan dari segi usia, sebagian besar subjek berusia 30-40 tahun sebanyak 41 orang (35\%). Sedangkan berdasarkan status pernikahan, sebagian besar subjek berstatus menikah dengan frekuensi sebanyak 93 orang $(79 \%)$.

Tabel 1. Profil Subjek

\begin{tabular}{cccc}
\hline \multicolumn{2}{c}{ Profil } & Frekuensi & Persentase \\
\hline Jenis & Wanita & 58 & 49 \\
Kelamin & Pria & 60 & 51 \\
& $<30$ th & 18 & 15 \\
Usia & $30-40$ th & 41 & 35 \\
& $41-50$ th & 36 & 31 \\
& $>50$ th & 23 & 19 \\
Status & Belum & 25 & 21 \\
Pernikahan & Menikah & & \\
& Menikah & 93 & 79 \\
\hline
\end{tabular}

Dalam rangka mengetahui persepsi subjek tentang kesejahteraan psikologis, maka dilakukan pengkategorian nilai skor pada aitem-aitem yang valid (Azwar, 2012). Berikut ini disajikan distribusi kategori kesejahteraan psikologis yang dibagi menjadi tiga kategori yaitu rendah, sedang, dan tinggi seperti yang tercantum dalam Tabel 2. Berdasarkan data di Tabel 2 dapat diketahui bahwa secara keseluruhan subjek memiliki persepsi terhadap kesejahteraan psikologis dengan kategori sedang dan tinggi. Sebagian besar subjek penelitian memiliki persepsi tinggi pada kesejahteraan psikologis, yaitu ada 95 orang (80.5\%), sedangkan sisanya yaitu dengan frekuensi 23 orang (19.5\%) memiliki kategori kesejahteraan psikologis sedang.

Tabel 2. Distribuasi Kategori Kesejahteraan Psikologis

\begin{tabular}{llcc}
\hline Kategori & $\begin{array}{c}\text { Skor } \\
\text { Total }\end{array}$ & $\begin{array}{c}\text { Fre- } \\
\text { kuensi }\end{array}$ & $\begin{array}{c}\text { Persen- } \\
\text { tase }\end{array}$ \\
\hline Rendah & $\leq 70$ & 0 & 0 \\
Sedang & $71-100$ & 23 & 19.5 \\
Tinggi & $\geq 110$ & 95 & 80.5 \\
Total & & 118 & 100 \\
\hline
\end{tabular}

Selanjutnya dilakukan tabulasi silang (cross tabulation) yang merupakan teknik dalam menganalisa data berdasarkan kelompok, ketegori, atau kelas. Hal ini bertujuan untuk memeriksa dan membandingkan perbedaan antar kelompok. Dalam penelitian ini, tabulasi silang digunakan untuk mengetahui hubungan antara jenis kelamin dengan kesejahteraan psikologis. Hasilnya ditemukan bahwa sebagian besar subjek memiliki kesejahteraan psikologis dengan kategori tinggi, hal ini ditunjukkan dengan total frekuensi sebanyak 95 orang $(80.5 \%)$ dari total 118 orang subjek. Dari data yang ditemukan, keseluruhan subjek dengan jenis kelamin wanita memiliki kesejahteraan psikologis dalam kategori tinggi, yaitu sebanyak 58 orang. Sementara itu, sebagian besar subjek berjenis kelamin pria memiliki kesejahteraan psikologis dalam kategori tinggi hanya sebanyak 37 orang $(61.7 \%)$ dari total 60 orang pria, sedangkan sisanya sebanyak 23 orang $(38.3 \%)$ berkategori sedang.

\section{Pembahasan}

Penelitian ini bertujuan untuk mengetahui gambaran mengenai kesejahteraan psikologis pada karyawan yang terdampak pandemi COVID-19. Hasil menunjukkan 
bahwa jumlah subjek memiliki skor yang berada pada kategori tinggi yakni sebesar $80.5 \%$. Tingginya tingkat kesejahteraan psikologis ini dimiliki oleh sebagian besar subjek wanita, dimana sebanyak 58 subjek wanita mendapatkan skor tinggi dan hanya 37 subjek pria yang mendapatkan skor tinggi, serta 23 subjek pria yang mendapatkan skor rendah. Hal ini menyimpulkan bahwa subjek dengan jenis kelamin wanita cenderung memiliki kesejahteraan psikologis yang lebih tinggi jika dibandingkan dengan subjek pria.

Hasil ini selaras dengan hasil penelitian Cicognani (2011) yang menemukan bahwa remaja wanita memiliki kesejahteraan psikologis yang lebih tinggi dibandingkan pria. Remaja yang lebih tua juga ditemukan memiliki tingkat kesejahteraan psikologis yang lebih tinggi jika dibandingkan dengan remaja yang lebih berusia muda. Hasil penelitian ini juga mengkonfirmasi hasil penelitian Vinayak dan Judge (2018) yang mengeksplorasi kesejahteraan psikologis pada polisi pria dan wanita. Hasil penelitian tersebut menunjukkan bahwa polisi wanita memiliki skor kesejahteraan psikologis yang lebih tinggi daripada polisi pria.

Faktor-faktor demografis lain seperti usia dan status penikahan juga ditemukan berkaitan dengan kondisi kesejahteraan psikologis subjek penelitian ini. Merujuk pada Ryff (1989), status pernikahan, usia, dan pendidikan memang merupakan faktor penting dalam memengaruhi tingkat kesejahteraan psikologis individu. Tingkat kesejahteraan psikologis yang tinggi pada subjek wanita sesuai hasil penelitian ini juga ditentukan oleh faktor-faktor demografis tersebut.

Pada penelitian ini sebagian besar subjek berada pada kelompok dengan status telah menikah. Hasil penelitian ini pada kategori wanita menikah tersebut selaras dengan hasil penelitian Apsaryanthi dan Lestari (2017) tentang dampak kondisi pandemi COVID-19 terhadap karyawan wanita yang telah menikah dan bekerja dari rumah. Penelitian tersebut menunjukkan bahwa karyawan Wanita yang bekerja dari rumah akan dapat menghemat energinya dan dapat menjalankan dua peran dalam waktu yang bersamaan. Oleh karena itu, terdapat efek positif yang dirasakan ketika seorang wanita menjadikan rumahnya juga sebagai tempat kerjanya yakni dapat mengatur waktu luangnya dan berkumpul dengan keluarga. Selain itu, efek positif lainnya seperti, meningkatkan keeratan hubungan antar anggota keluarga, dan meningkatkan kepuasan hidup keluarga (Ahtrenzen, 1990; Rowe \& Bentley, 1992; Zhang et al., 2020)

Tingginya tingkat kesejahteraan psikologis pada wanita yang diperoleh dalam penelitian ini juga dapat disebabkan karena sebagian besar subjek berada pada kelompok usia 30-40 tahun. Persepsi individu dewasa muda mengenai kesejahteraan psikologis secara umum akan meningkat pada usia 30 tahun (Switek \& Easterlin, 2018). Ditambahkan Pourebrahim dan Rasouli (2019), bahwa rata-rata kesejahteraan psikologis pada wanita dewasa lebih tinggi jika dibandingkan dengan kelompok usia dewasa tua dan lansia. Terjadinya hal tersebut dapat disebabkan karena karyawan pada usia 30 hingga 40 tahun memiliki keinginan untuk dapat melindungi konsep diri, lebih termotivasi, dan bersemangat dalam berjuang untuk kemajuan dan pengakuan diri (Rabl, 2010).

Penelitian ini juga memeroleh data tabulasi silang skor yang diperoleh subjek, antara jenis kelamin dengan setiap dimensi dari kesejahteraan psikologi. Dimensi dari Ryff (1989) yaitu penerimaan diri, hubungan positif dengan orang lain, otonomi, penguasaan lingkungan, tujuan hidup, dan perkembangan pribadi. Ditemukan bahwa subjek dengan jenis kelamin wanita memperoleh persentase yang lebih tinggi dibandingkan dengan pria pada keseluruhan dimensi kesejahteraan psikologis. Terdapat dimensi tujuan hidup yang merupakan dimensi dengan persentase paling tinggi sebesar $91.5 \%$, dimana sebanyak $100 \%$ atau keseluruhan dari subjek wanita memiliki kategori tinggi, dan $83.3 \%$ pada subjek pria. Menurut Ryff (2014), skor tinggi pada dimensi tujuan hidup yaitu dimana individu 
memiliki tujuan dalam hidup dan perasaan terarah, merasa memiliki makna untuk kehidupan sekarang ataupun masa lalu, memegang keyakinan dalam memberikan tujuan hidup, serta memiliki maksud dan tujuan untuk hidup. Sementara itu, skor rendah menunjukkan individu yang tidak memiliki rasa kebermaknaan dalam hidup, hanya memiliki sedikit tujuan, kurang memiliki arah, tidak melihat tujuan dalam kehidupan lampau, tidak memiliki pegangan yang memberikan makna dalam hidup.

Hasil penelitian ini juga mengkonfirmasi hasil penelitian Lapa (2015) yang membandingkan kesejahteraan psikologis menurut jenis kelamin dan tingkat aktivitas fisik mahasiswa. Penelitian tersebut menemukan bahwa terdapat perbedaan yang signifikan antara kesejahteraan psikologis menurut tingkat aktivitas fisik dan jenis kelamin. Berkaitan dengan kesejahteraan psikologis, mahasiswa wanita memeroleh skor yang lebih tinggi pada dimensi tujuan hidup dan perkembangan pribadi dibandingkan mahasiswa pria. Penelitian Perez (2012) tentang perbedaan gender dalam berbagai aspek kesejahteraan psikologis pada mahasiswa Filipina juga menunjukkan bahwa terdapat perbedaan dalam beberapa dimensi kesejahteraan psikologis pada subjek pria dan wanita. Mahasiswa wanita memeroleh skor lebih tinggi pada dimensi tujuan hidup dan dimensi hubungan positif.

Sebagaimana yang dikemukakan oleh (Ryff, 1989), dimensi tujuan hidup meliputi adanya tujuan, niat dan arah yang dimiliki individu sehingga mereka akan memiliki keyakinan bahwa hidup itu bermakna. Adanya hal tersebut maka karyawan yang terdampak pandemi COVID-19 hendaknya tidak terus-menerus mengalami keterpurukan dan menyalahkan keadaan pandemi COVID-19 yang terjadi. Sebaliknya, karyawan perlu mampu menemukan strategi lain dalam menyelesaikan pekerjaan sehingga tujuan hidup dalam bekerja dapat tercapai. Bagi karyawan yang bekerja pada institusi pendidikan dan terdampak akibat adanya pandemi COVID-19 tentu bukanlah hal yang mudah untuk dilewati, tidak sedikit karyawan-karyawan yang merasa tertekan karena ketidaksiapannya mengelola dan menyelesaikan pekerjaan dari rumah tanpa melakukan kegiatan tatap muka secara langsung. Walau demikian, dalam menyiasati kondisi tersebut, banyak cara yang dapat dilakukan agar proses pemberian pendidikan tetap berjalan secara efektif, seperti melakukan video meeting ataupun menggunakan metode lainnya. Dalam hal ini, wanita cenderung lebih cepat dalam menemukan solusi atau strategi coping guna mengatasi permasalahannya tersebut, dan cenderung memandang permasalahan tersebut dengan cara yang lebih luas (Cicognani, 2011). Halhal inilah yang mungkin memengaruhi skor tujuan hidup pada jenis kelamin Wanita menjadi lebih tinggi dibandingkan pria.

Selanjutnya, dimensi hubungan positif dengan orang lain memeroleh persentase tinggi sebesar $85.6 \%$. Ada $98.3 \%$ subjek wanita memiliki dimensi ini, sedangkan pada pria $70 \%$ subjek yang berkategori tinggi. Ryff (2014) mengemukakan bahwa skor tinggi pada dimensi hubungan positif dengan orang lain, yakni individu memiliki hubungan yang hangat, memuaskan, dan penuh kepercayaan dengan orang lain, peduli dengan kesejahteraan orang lain, memahami dan menerima hubungan antar individu serta memiliki empati, kasih sayang dan keintiman yang kuat. Sementara itu, pada skor rendah indivdu tidak banyak memiliki hubungan yang dekat dan saling percaya dengan orang lain, merasa sulit untuk terbuka dan peduli dengan orang lain, terisolasi dan frustasi dalam hubungan interpersonal, serta tidak mau berkompromi untuk mempertahankan ikatan yang penting dengan orang lain.

Penelitian lainnya oleh Akram (2019) menemukan bahwa secara keseluruhan guru pria dan wanita memiliki tingkat kesejahteraan psikologis yang serupa. Namun, guru wanita memeroleh skor yang lebih tinggi pada dimensi membangun hubungan positif dan penerimaan diri. Selain itu, guru wanita di sekolah swasta memiliki skor tinggi pada tujuan hidup daripada guru pria. Penelitian Páez-Gallego et al. (2020) yang mengkaji 
hubungan kesejahteraan psikologis remaja dengan gaya pengambilan keputusan juga menemukan adanya perbedaan yang signifikan pada kesejahteraan psikologis wanita dan pria. Remaja wanita memiliki hasil yang lebih tinggi pada dimensi hubungan positif dengan orang lain dan perkembangan pri-badi daripada hasil yang diperoleh remaja pria, meskipun perbedaannya kecil.

Saat menjalankan pekerjaan yang dilakukan dari rumah selama masa pandemi COVID-19 ini, seorang karyawan juga harus berinteraksi dengan anggota yang ada di rumah. Bagi seorang karyawan wanita yang telah menikah, menjadi peran sebagai ibu ataupun istri tentu menjadi beban tambahan karena di saat yang bersamaan juga harus menyelesaikan pekerjaan kantor di rumah. Salah satu cara dalam meredam stresor tersebut di ataranya adalah dengan meningkatkan regulasi emosi dan membangun hubungan interpersonal yang lebih intim dengan anggota keluarga, adanya kemampuan ini sangat berkaitan erat dengan bagaimana kesejahteraan psikologis individu (Marliani et al., 2020).

Selain itu, wanita memiliki pola pikir yang dapat dengan cepat menemukan strategi coping dan menjalankan aktivitas sosial, sehingga kemampuan interpersonal yang dimiliki wanita menjadi lebih baik daripada laki-laki (Cicognani, 2011). Oleh sebab itu, dimensi hubungan positif dengan orang lain pada wanita mendapatkan skor yang lebih tinggi jika dibandingkan dengan pria (Kartikasari, 2013; Ryff \& Keyes, 1995; Ryff \& Singer, 1998). Berbagai hasil penelitian terdahulu dan wawasan teoritis tersebut dapat menjelaskan mengapa tingkat dimensi hubungan positif dengan orang lain dari variabel kesejahteraan psikologis cenderung lebih tinggi pada wanita daripada pria.

Dimensi ketiga dengan persentase yang cukup tinggi yakni dimensi perkembangan pribadi sebesar $81.4 \%$. Pada subjek wanita memeroleh skor berkategori tinggi sebesar $93.1 \%$, dan subjek pria mendapatkan skor berkategori tinggi sebesar $70 \%$. Dimensi perkembangan pribadi pada skor tinggi menunjukkan karakteristik individu yang memiliki kesadaran untuk terus berkembang secara berkala, terbuka akan pengalaman baru, menyadari potensi diri, serta melihat peningkatan diri dari waktu ke waktu.

Sementara itu untuk skor rendah pada dimensi perkembangan pribadi yaitu dimana individu kurang menginginkan untuk melakukan peningkatan diri dari waktu ke waktu, merasa bosan dan tidak tertarik dengan hidup, serta merasa tidak mampu mengembangkan sikap ataupun perilaku baru (Ryff, 2014). Zubieta et al. (2012) meneliti kesejahteraan psikologis dan subjektif dengan menggunakan indikator-indikator yang berbeda dan menemukan bahwa wanita memiliki skor yang lebih tinggi pada dimensi perkembangan diri, sedangkan pria pada dimensi kebebasan.

Ketika sedang berada pada masa pandemi COVID-19 seperti saat ini dan diberlakukannya sistem pembatasan sosial berskala besar yang menuntut karyawan menjalankan pekerjaannya dari rumah, berbagai kesulitan untuk mengembangkan diri tentu saja dapat dialami. Proses pengembangan diri pada karyawan yang bekerja di institusi pendidikan biasanya dapat dilakukan dengan pemberian pelatihan dengan berbagai metode, seperti menempatkan karyawan secara langsung di tempat kerjanya, melakukan demonstrasi, ataupun melakukan suatu pertemuan di dalam kelas (Zuhri, 2014).

Metode-metode pengembangan diri untuk karyawan ini tentunya belum dapat direalisasikan secara optimal dalam keadaan pandemi COVID-19. Walaupun demikian, wanita lebih dapat melakukan perkembangan diri dengan memulai hobi-hobi baru yang dapat dilakukan di dalam rumah. Harikrishnan dan Sailo (2020) menemukan bahwa selama diberlakukannya lockdown, wanita lebih tertarik dalam melakukan minat dan hobi baru sehingga mereka menjadi lebih aktif secara fisik dan sosial, seperti membersihkan rumah, olahraga, perawatan badan, dan berkebun, sedangkan pria lebih banyak melakukan isolasi diri selama masa lockdown. Hal inilah yang 
dapat menjadi pengaruh tingginya skor dimensi perkembangan pribadi pada subjek berjenis kelamin wanita.

Beberapa penelitian terdahulu memperkuat hasil yang telah ditemukan, seperti penelitian Matud et al (2019) yang menguji relevansi gender dengan kesejahteraan psikologis pada individu dewasa. Subjek yang digunakan adalah laki-laki dan perempuan dari populasi umum dengan rentang usia 21-64 tahun. Hasilnya ditemukan bahwa wanita mendapat skor yang lebih tinggi pada perkembangan pribadi dan hubungan positif dengan orang lain, sedangkan pria mendapat skor tinggi pada penerimaan diri dan kemandirian. Alandete (2013) juga meneliti kesejahteraan psikologis berdasarkan jenis kelamin dan umur pada mahasiswa. Hasil penelitiannya menunjukkan bahwa wanita mengungguli pria pada dimensi hubungan positif dengan orang lain, penerimaan diri, penguasaan lingkungan, perkembangan diri, dan tujuan hidup.

Kesejahteraan psikologis individu tentunya bukan hanya disebabkan oleh perbedaan jenis kelamin, melainkan kondisi pandemi COVID-19 juga memberikan dampak terhadap kondisi psikologis individu. Sebagaimana penelitian López et al (2020) yang mengkaji hubungan antara usia dan kesejahteraan psikologis dengan fokus pada dimensi perkembangan pribadi dan tujuan hidup. Hasil penelitian menemukan bahwa dampak pandemi COVID-19 memiliki relevansi yang sedikit bagi orang tua, karena kesejahteraan psikologis orang dewasa yang lebih tua tergantung dari cara mereka melakukan penilaian dan kemampuan mereka dalam mengelola masalah terkait dengan pandemi COVID-19. Selanjutnya penelitian Prasad et al. (2020) yang bertujuan untuk mengetahui pengaruh stres kerja dan kerja jarak jauh (work from home) terhadap kesejahteraan psikologis karyawan. Hasilnya menunjukkan beberapa faktor seperti rekan kerja, ambiguitas peran, iklim organisasi, dan kepuasan kerja memiliki pengaruh yang signifikan terhadap kesejahteraan psikologis karyawan. Perbedaan gender dan ke- lompok usia juga memberikan pengaruh yang signifikan terhadap kesejahteraan psikologis karyawan.

\section{Simpulan}

Dari hasil penelitian dan pembahasan di atas, dapat disimpulkan bahwa karyawan yang terdampak pandemic COVID-19 memiliki skor kesejahteraan psikologis pada kategori tinggi sebesar $80.5 \%$, sedangkan sebanyak $19.5 \%$ masuk ke dalam kategori sedang. Selanjutnya dimensi tujuan hidup dan hu-bungan positif dengan orang lain merupa-kan dimensi dengan perolehan skor lebih tinggi dibandingkan dengan dimensi lainnya, namun subjek berjenis kelamin wanita memeroleh persentase yang lebih tinggi dibandingkan dengan pria pada keseluruhan dimensi dari kesejahteraan psikologis. Berdasarkan hasil tersebut dapat disimpulkan bahwa kesejahteraan psikologis karyawan wanita lebih tinggi dibandingkan dengan kesejahteraan psikologis pada karyawan pria.

\section{Saran}

Pada penelitian selanjutnya, disarankan untuk meneliti topik kesejahteraan psikologis pada situasi khusus seperti pandemi COVID-19 atau situasi darurat lain dengan menambahkan variabel-variabel lain yang relevan untuk menggambarkan dampak situasi tersebut. Selain itu, jumlah subjek penelitian yang lebih besar menjadi penting dalam penelitian survei semacam ini, serta menggunakan subjek dengan karakteristik yang beragam.

Pada pengambil kebijakan, disarankan untuk memonitor dan memberikan layanan psikologis pada para karyawannya yang dapat dilakukan secara online untuk menjaga kesejahteraan psikologis mereka. Hal ini penting untuk dilakukan karena adanya kesejahteraan psikologis yang dimiliki para karyawan tersebut akan berdampak pada kinerja. 


\section{Daftar Pustaka}

Ahtrenzen, S. B. (1990). Managing conflict by managing boundaries: How professional homeworkers cope with multiple roles at home. Environment and Behavior, 22(6), 723-753. https://doi.org/10.1177\%2F00139165 90226001

Aisyah, A., \& Chisol, R. (2018). Rasa syukur kaitannya dengan kesejahteraan psikologis pada guru honorer. Jurnal Pikologi Proyeksi, 13(2), 109-122. http://jurnal.unissula.ac.id/index.php/ proyeksi/article/view/3953

Akram, M. (2019). Psychological Wellbeing of University Teachers in Pakistan. Journal of Education and Educational Development, 6(2), 235253.

https://doi.org/10.22555/joeed.v6i2.2 473

Alandete, J. G. (2013). Psychological wellbeing, age, and gender among spanish undergraduates. Health \& Society, 4(1), 48-58. http://pepsic.bvsalud.org/pdf/salsoc/v 4n1/4n1a04.pdf

Apsaryanthi, N. L. K., \& Lestari, M. D. (2017). Perbedaan Tingkat Psychological Well-Being Pada Ibu Rumah Tangga Dengan Ibu Bekerja Di Kabupaten Gianyar. Jurnal Psikologi Udayana, 4(1), 110-117. https://doi.org/10.24843/jpu.2017.v04 .i01.p12

Awaliyah, A., \& Listiyandini, R. A. (2018). Pengaruh rasa kesadaran terhadap kesejahteraan psikologis pada mahasiswa. Journal Psikogenesis, $5(2)$, 89-101. https://doi.org/10.24854/jps.v5i2.498

Azwar, S. (2019). Penyusunan Skala Psikologi. Pustaka Pelajar.
Bozkurt, A., \& Sharma, R. C. (2020). Emergency remote teaching in a time of global crisis due to CoronaVirus pandemic. Asian Journal of Distance Education, 15(1), 1-6. http://dx.doi.org/10.5281/zenodo.377 8083

Cho, S. (2019). Effects of social support and grateful disposition on employees' psychological well-being. Service Industries Journal, 39(11-12), 799819.

https://doi.org/10.1080/02642069.201 8.1444755

Cicognani, E. (2011). Coping Strategies With Minor Stressors in Adolescence: Relationships With Social Support, Self-Efficacy, and Psychological Well-Being. Journal of Applied Social Psychology, 41(3), 559-578. https://doi.org/10.1111/j.1559-

1816.2011.00726.x

Flores, M. A., \& Gago, M. (2020). Teacher education in times of COVID-19 pandemic in Portugal: national, institutional and pedagogical responses. Journal of Education for Teaching, 46(4), 507-516. https://doi.org/10.1080/02607476.202 0.1799709

Harikrishnan, U., \& Sailo, G. L. (2020). Mizo Youth and the COVID Lockdown Life: A Gender Comparison. International Journal of Research and Review, 7(8), 221-225. https://www.ijrrjournal.com/IJRR_Vo 1.7_Issue.8_Aug2020/Abstract_IJRR0 027.html

Huppert, F. A. (2009). Psychological Wellbeing: Evidence Regarding its Causes and Consequences. Applied Psychology: Health and Well-Being, l(2), 137-164. https://doi.org/10.1111/j.17580854.2009.01008.x 
Idris, I., Khairani, A. Z., \& Shamsuddin, H. (2019). The influence of resilience on psychological well-being of Malaysian University undergraduates. International Journal of Higher Education, 8(4), 153-163. https://doi.org/10.5430/ijhe.v8n4p153

Kartikasari, N. Y. (2013). Body dissatisfaction terhadap psychological well-being pada karyawati. Jurnal Ilmiah Psikologi Terapan, 1(2), 304323.

https://ejournal.umm.ac.id/index.php/j ipt/article/view/1585

Lapa, T. Y. (2015). Physical Activity Levels and Psychological Well-Being: A Case Study of University Students. Procedia-Social and Behavioral Sciences, 186, 739-743. https://doi.org/10.1016/j.sbspro.2015. 04.122

López, J., Perez-Rojo, G., Noriega, C., Carretero, I., Velasco, C., MartinezHuertas, J. A., López-Frutos, P., \& Galarraga, L. (2020). Psychological well-being among older adults during the COVID-19 outbreak: A comparative study of the young-old and the old-old adults. International Psychogeriatrics, 32(11), 1365-1370. https://doi.org/10.1017/S1041610220 000964

Marliani, R., Nasrudin, E., Rahmawati, R., \& Ramdani, Z. (2020). Regulasi Emosi, Stres, dan Kesejahteraan Psikologis: Studi Pada Ibu Work from Home dalam Menghadapi Pandemi COVID-19. Project: Psychometric Properties of Psychological Constructs.https://www.researchgate. net/publication/341150701

Matud, M. P., López-Curbelo, M., \& Fortes, D. (2019). Gender and psychological well-being. International Journal of Environmental Research and Public Health, 16(19), 1-11. https://doi.org/10.3390/ijerph16193531
Páez-Gallego, J., Gallardo-López, J. A., López-Noguero, F., \& RodrigoMoriche, M. P. (2020). Analysis of the Relationship Between Psychological Well-Being and Decision Making in Adolescent Students. Frontiers in Psychology, 11, 1-13. https://doi.org/10.3389/fpsyg.2020.01 195

Perez, J. A. (2012). Gender difference in psychological well-being among Filipino college student samples. International Journal of Humanities and Social Science, 2(13), 84-93. http://www.ijhssnet.com/journals/Vol _2_No_13_July_2012/8.pdf

Pourebrahim, T., \& Rasouli, R. (2019). Meaning of Life and Psychological Well-Being during Adult, Older Adult and Oldest Old. Elderly Health Journal, 5(1), 40-46. https://doi.org/10.18502/ehj.v5i1.1198

Prasad, K., Vaidya, R. W., \& Mangipudi, M. R. (2020). Effect of occupational stress and remote working on psychological well-being of employees: An empirical analysis during covid-19 pandemic concerning information technology industry in hyderabad. Indian Journal of Commerce \& Management Studies, 11(2), 1-13. https://doi.org/10.18843/ijcms/v11i2/01

Purwanto, A. (2020). Studi eksplorasi Dampak WFH Terhadap Kinerja Guru. EduPsyCouns: Journal of Education, Psychology and Counseling, 2(1), 92-100. https://ummaspul.ejournal.id/Edupsycouns/article/view/4 18

Rabl, T. (2010). Age, discrimination, and achievement motives: A study of German employees. Personnel Review, 39(4), 448-467. https://doi.org/10.1108/00483481011 045416 
Rokhani, C. T. S. (2020). Pengaruh Work From Home (WFH) Terhadap Kinerja Guru SD Negeri Dengkek 01 Pati Selama Masa Pandemi Covid-19. EduPsyCouns: Journal of Education, Psychology and Counseling, 2(1), 424-437. https://ummaspul.ejournal.id/Edupsycouns/article/view/5 00

Rowe, B. R., \& Bentley, M. T. (1992). The impact of the family on home-based work. Journal of Family and Economic, 13, 279-297. https://doi.org/10.1007/BF01020452

Ryff, C. D. (1989). Happiness is everything, or is it? Explorations on the meaning of psychological wellbeing. Journal of Personality and Social Psychology, 57(6), 1069-1081. https://psycnet.apa.org/doi/10.1037/0 022-3514.57.6.1069

Ryff, C. D. (2014). Psychological wellbeing revisited: Advances in the science and practice of eudaimonia. Psychotherapy and Psychosomatics, 83(1), $10-28$. https://doi.org/10.1159/000353263

Ryff, C. D., \& Keyes, C. L. M. (1995). The Structure of Psychological Well-Being Revisited. Journal of Personality and Social Psychology, 69(4), 719-727. https://doi.org/10.1037/00223514.69.4.719

Ryff, C. D., \& Singer, B. (1998). The Contours of Positive Human Health. Psychological Inquiry, 9(1), 1-28. https://doi.org/10.1207/s15327965pli 0901_6

Setyawati, M. B., \& Murniati, M. (2018). Stres, Stresor dan Koping Stres Pada Mahasiswa Keperawatan dan Kebidanan di STIKES Harapan Bangsa Purwokerto. Viva Medika: Jurnal Kesehatan, Kebidanan Dan Keperawatan, 10(1), 6-12. https://doi.org/10.35960/vm.v10i1.397
Switek, M., \& Easterlin, R. A. (2018). Life Transitions and Life Satisfaction During Young Adulthood. Journal of Happiness Studies, 19(1), 297-314. https://doi.org/10.1007/s10902-0169817-y

Syahrial. (2020). Dampak Covid-19 terhadap Tenaga Kerja di Indonesia. Jurnal Ners, 4(2), 21-29. https://journal.universitaspahlawan.ac .id/index.php/ners/article/view/1022

Talidong, K. J. B., \& Toquero, C. M. D. (2020). Philippine Teachers' Practices to Deal with Anxiety amid COVID-19. Journal of Loss and Trauma, 25(6-7), 573-579.

https://doi.org/10.1080/15325024.202 0.1759225

Vinayak, S., \& Judge, J. (2018). A Study of Psychological Well-Being among Police Personnel. International Journal of Health Sciences and Research, 8(9), 190-198. https://www.ijhsr.org/IJHSR_Vol.8_I ssue.9_Sep2018/27.pdf

Zhang, S., Moeckel, R., Moreno, A. T., Shuai, B., \& Gao, J. (2020). A worklife conflict perspective on telework. Transportation Research Part A: Policy and Practice, 141(A), 51-68. https://doi.org/10.1016/j.tra.2020.09.0 07

Zubieta, E., Muratori, M., \& Fernández, O. (2012). Bienestar subjetivo y psicosocial: Explorando diferencias de género. Salud \& Sociedad, 3(1),66-76. https://doi.org/10.22199/s07187475.2 012.0001 .00005

Zuhri, M. M. (2014). Pengembangan sumber daya guru dan karyawan dalam organisasi pendidikan. Quality: Journal of Empirical Research in Islamic Education, 2(2), 205-221. https://journal.iainkudus.ac.id/index.p hp/Quality/article/view/2108 